\title{
The effect firm characteristic on corporate social responsibility disclosure in the firms listed in Indonesia Sharia Stock Index
}

\author{
Ahmad Rifani Irham*; Sa’adah Yuliana; Marlina Widiyanti \\ Faculty of Economics, Universitas Sriwijaya, Indonesia
}

*To whom correspondence should be addressed. Email: Ahmadrifani.irham@gmail.com

\begin{abstract}
This study aims to analyze the effect of firm characteristics of corporate social responsibility disclosure. The population in this study is as many as 143 companies listed in the Indonesia Sharia Stock Index, whereas units of analysis in this study were 43 companies listed in the Indonesia Sharia Stock Index for the period 2012-2016. The type of data used is secondary data with multiple linear regression analysis. The result shows that firm size and profitability have significant influence, while leverage and firm growth have no significant effect on corporate social responsibility disclosure. This study supports signaling theory in which the information presented will be a good signal for external parties for sustainable development for the company.
\end{abstract}

Keywords: Corporate social responsibility, Firm size, Leverage, Profitability

JEL Classification: G1, G32, M14

\section{INTRODUCTION}

Social responsibility disclosure is the concept that a firm has a variety of responsibility to all the stakeholders in all factors of activities related to environment, social and economy. Therefore, social responsibility is closely related to the firm life sustainability.

The report about social responsibility which was voluntary based has become obligatory with the turning up of the law number 40 of 2007 concerning limited company. The law explains that annual report should provide much information, including the report of environment implementation and social responsibility (Maulida, 2014).

The effect of social impact on firms tends to be difference although the firms are in the same kind of business. Some factors which distinguish the effect from firm social effect are firm characteristic, such as size (size of firm), liquidity, profitability, leverage, firm age, firm profit, board of director structure and others.

In Islamic point of view, CSR can be defined as humanity activity or charity activity performed by a moslem to help the needy by means of zakat, infaq, and shodaqoh. Prior to CSR, zakat, infaq, and shodaqoh (ZIS) have come first because they are regulated in Alquran in At-Taubah at verses 60:103.

Indonesian Sharia Stock Index or better. Known as ISSI are all the sharia stocks listed in the Islamic effect and BEI list. On may the twelfth, 2011 ISSI issued the calculation method by using the average balanced form the market capitalization.

The firm size can classify how progressive the frame is, by indicating the amount of sales, total asset, human resource, stock values and so on, Andriyani (2014). Asset 
value usually have more stable value than sale and market capitalization by considering asset values as business size. Firm size of a firm indicates the amount of experience, rate of risk and the ability to manage investment to improve the firm prosperity.

Profitability in the firm effect to gain profit which will maintain both long period and shot period sustainability of the firm is profitability is high, social disclosure should also be higher (Hackston \& Milne, 1996). Profitability is the variable which explains the variation in taking the firm social responsibility (Chauhan, 2014). Chauhan Research has found that profitability has positive effect on social responsibility disclosure.

Leverage is ratio of debt against capital, which illustrates a number of firm's assets imposed on by the external parties than its own capital. If the firm's debt is big, the risk to hold will get higher. The high rate of leverage in firm usually decreases the activity of social responsibility disclosure. According to Belkaouii in Marfuah (2011), the decision in providing social report results in the firm burden, which causes the decrease of the firm's income in Marfuah's research, leverage has significant negative effect on social responsibility disclosure.

Firm growth becomes the investors' consideration to invest. The firm which has distinct progress in striving to give much contribution in the future, hoping for best profit in so that the investors are interested in putting investment. The high growth will put the firm in the sport light so the firm is expected to perform more social responsibility (Sari,2012).

Based on the phenomena and background explained before, this research explain the effect firm characteristics on corporate social responsibility disclosure in the firms listed in Indonesia Sharia Stock Index.

\section{LITERATURE REVIEW}

\section{Signaling theory}

Signal is the step taken by the firm to give direction to investors about the firm's future goal. The signal in the information about the activities already performed by the management to realize the owner's expectation. The information from the firm will bring effect to the act of investing by the external parties. This information is important because the firm shows notes and illustration which contains about the firm's part, recent and future condition (Brigham, 2001).

Signaling theory mentions that the firm has the stimulus in sharing information about financial report for the external parties. This matters because there is asymmetrical information between the firm and external parties because the firm knows more about the information and future prospect than the external parties. The lack of information makes the external parties more alert by offering not high price to the firm. The firm value can be increased by restricting the asymmetrical information, including the sharing of signal with the external parties (Arifin, 2005).

\section{Firm size}

It is the value that shows the firm value where if the scale is big, there will be more information revealed than small scale firm. It is clear that the big scale firm is regarded by the public as the firm has important role and is able to perform social responsibility.

Total assets are used as the measuring tool from the firm size. In Elzahar and Hussainey's research (2012), the firm size in using the amount of assets is identified to give significant effect on the interim financial report risk information of the firm in England. A big firm will get the spotlight from the public so that the firm will perform disclosure as the proof of its social responsibility (Purwanto, 2011). 


\section{Profitability}

It is the effort of the firm achievement in one certain period. The profitability calculation guideline is the financial report in the forms of balance sheet and profit loss. From this report can be concluded analysis calculation can be reached to determine various aspect of firm activities (Oktania, 2013).

Profitability analysis is untended to review the profit achievement level, such as its relationship with the assets, sales, or own capital hence, profitability result can be basic accuracy of target for the firm performance that can be seen from the profit produced from sales or investment.

\section{Leverage}

Leverage shows the debt composition of debt against the stock holder's capital, which indicates how big the relationship of the firm debt is in the firm operational activity. If leverage is high, it will cause the high risk of finance which becomes the debt holders' concerns, so that the firm attempts to in form bigger profit and report the social information disclosure as well as possible (Anugrah, 2010).

\section{Firm growth}

Firm growth be comes the thing that investors can imagine in putting investment because it can illustrate financial performance progress which is measured with the sale level the fir which is predicted to be able to develop rapidly is expected to make high profit in the future, then attract investors to invest. The firm which is based on social responsibility because it becomes the sport light (Purwanto, 2011).

\section{Corporate social responsibility}

According to CSR forum (Wibisono, 2007 in Setyo 2012), Social Responsibility is defined as the activity performed transparently and based on moral values, which hold firmly to the mutual respect with the society and environment. The term CSR is closely related to the society and big scale firm. In essence, CSR is the form attention from the firm to the society and its surrounding environment.

Corporate social responsibility, according to World Business Council for Sustainable Development (WBCSD) is the advanced approval from the firm to contribute properly to the economic business development unit in the around environment and to improve the employees and their family's prosperity. While, according to ISO 26000, the characteristic of social responsibility is the firm effort to make decision with consideration to environment social aspect and to be responsible for the impact of society activity and environment.

\section{Corporate social responsibility disclosure}

Social responsibility disclosure is the information intended for the stakeholder in order that the firm can give information about social responsibility which has been performed at certain period. The regulation about social responsibility activity is ruled in law number 40 of 2007 about the limited company, provision referred to regulation in section 74 (1) says: "The company which performs its business activity getting in touch with human resource is obliged to run social and environmental responsibility".

In Financial Accounting Standards No. 1 paragraph 9 explains about disclosure to land environment impact, which says: "The firm has to make additional report dealing with living environment or added value, especially for the firm which is closely related to mean resource such as living environment, employees and other stake holders who we it".

CSR disclosure is defined as the communication of the social and environmental impacts resulting from an organization's economic actions on particular interest groups 
and on society at large (Gray et al., 1996). It is necessary for executives to make efforts to facilitate the proper counselling and resource provision functions of the independent directorate system by disseminating information in a timely and appropriate manner to all concerned. Besides that, the establishment of relationship with external stakeholders enables the independent board members to access information sources and capture hands-on information. Knowledge sharing between the external and internal board members can be valuable to the board, and thus, enhances the decision-making process (Johansen and Pettersson, 2013).

\section{Related previous study}

The research that reviewed about firm size, leverage, profitability, types of industry, firm growth, and corporate social responsibility started from the research by Anugrah (2010) His research result started that firm size variable has positive effect on social responsibility disclosure. This is the same with the researches done by Purwanto (2011), Sari (2012), Setiawan (2013), Marina (2013), and Maulida (2014). However, Rindawati (2015) had another opinion that firm size does not have effect on social responsibility disclosure.

Besides that Widiyawati (2012) and Kamil (2012) found that profitability has effect on social responsibility has effect on social responsibility disclosure. This is the same with Purban (2015) and Aini (2015). Where is Handayati (2011) and Wakid (2013) had contrasting opinion that profitability does not have effect on social responsibility disclosure.

Then, the influence of leverage on social responsibility disclosure shows positive result, which was studied by Wakid (2013), Purban (2015), and Aini (2015). On the contrary, Utami (2012) and Sriayu (2013) stated that leverage does not have effect on social responsibility disclosure. Related to firm growth, Aini (2015) stated that firm growth has effect on social responsibility disclosure.

\section{Framework}

The framework in this research can be seen in the following chart

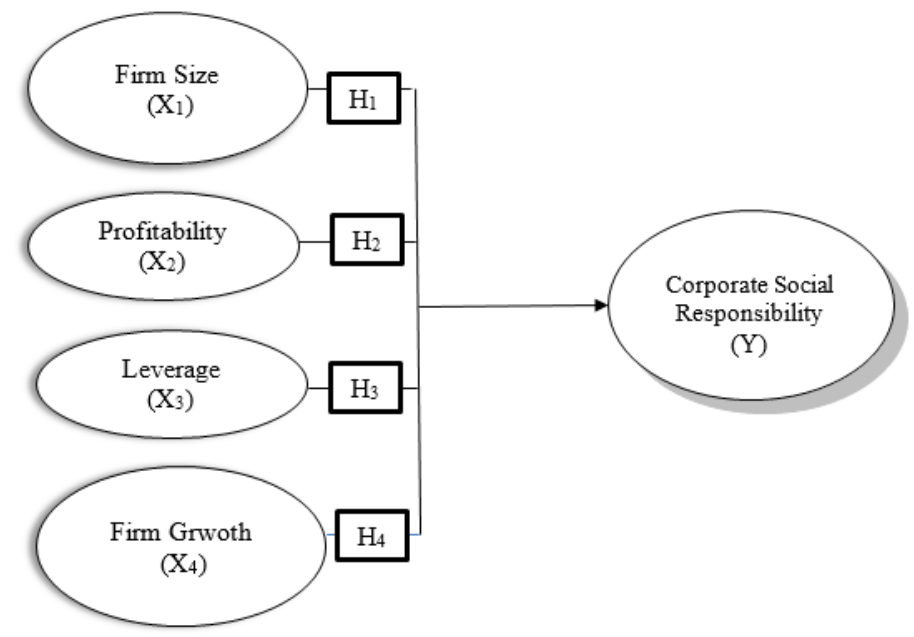

Figure 1. Framework

From the picture of the above framework, it can be seen that the first hypothesis shows that the Company Size directly influences Social Responsibility Disclosure and has a positive influence. Then the second hypothesis shows that Profitability has a direct effect on Social Responsibility Disclosure and has a positive influence. The third hypothesis shows that Leverage has a direct effect on Social Responsibility Disclosure and has a negative influence. The fourth hypothesis shows that Company Growth has a direct effect on Social Responsibility Disclosure and has a positive influence. 


\section{Hypothesis}

The hypothesis of this research is:

a. Firm size has positive effect on social responsibility disclosure.

b. Profitability has positive effect on social responsibility disclosure.

c. Leverage has negative effect on social responsibility disclosure.

d. Firm growth has positive effect on social responsibility disclosure.

\section{METHODS}

\section{The scope of the research}

This research is intended to explain about the subject concerning the effect of firm size, profitability, leverage, firm growth on social responsibility disclosure. To get the illustration about the subject, this research refers to empirical and theoretical studies in describing the relationship among the research variable. The intended object is the annual report and the financial report of the firms listed in Indonesian Islamic Stock Index in the official website of Indonesian Stock Exchange for the period of 2012-2016.

\section{Kind and sources of data}

The kind of data in this research is the secondary data, including the annual report of the firm listed in ISS, in the form of historical report about the firm's financial condition and performance. The annual report was obtained from Indonesian Stock Exchange Website and the firm's original websites. Besides that, the other secondary data were obtained from related previous study, articles, text books and other references related to the research.

\section{Population and sample}

This research used the population in the firms listed in Indonesian Islamic Stock Index (ISSI) from 2012 to 2016 by means of purposive sampling and in accordance with the determined criteria. 43 firm are treated as the samples, out of the total 132 population listed in BEI and the annual report has been issued for 5 years in succession, so the total of observation in this research is 215 .

Table 1. Company sample

\begin{tabular}{|c|c|c|c|c|c|}
\hline No. & Firm (Tbk) & Code & No. & Firm (Tbk) & Code \\
\hline 1 & Astra Agro Lestari & AALI & 23 & XL Asiata & EXCL \\
\hline 2 & Mahaka Media & ABBA & 24 & Indofarma (Persero) & INAF \\
\hline 3 & Ace Hardware Indonesia & ACES & 25 & Indofood Sukses Makmur & INDF \\
\hline 4 & Aneka Gas Industri & AGII & 26 & Indosat & ISAT \\
\hline 5 & Tiga Pilar Sejahtera Food & AISA & 27 & Kimia Farma (Persero) & KAEF \\
\hline 6 & Alakasa Industrindo & ALKA & 28 & Kabelindo Murni & KBLM \\
\hline 7 & Aneka Tambang (Persero) & ANTM & 29 & Kalbe Farma & KLBF \\
\hline 8 & Asiaplast Industries & APLI & 30 & Matahari Department Store & LPPF \\
\hline 9 & Arwana Citramulia & ARNA & 31 & Mayora Indah & MYOR \\
\hline 10 & Arthavest & ARTA & 32 & Ramayana Lestari Sentosa & RALS \\
\hline 11 & Astra International & ASII & 33 & Nippon Indosari Corpindo & ROTI \\
\hline 12 & Alam Sutera Realty & ASRI & 34 & Sindomulyo Selaras & SDMU \\
\hline 13 & Sepatu Bata & BATA & 35 & Sekar Bumi & SKBM \\
\hline 14 & Bhuwanatala Indah Permai & BIPP & 36 & Holcim Indonesia & SMCB \\
\hline 15 & BISI International & BISI & 37 & Semen Indonesia (Persero) & SMGR \\
\hline 16 & Sentul City & BKSL & 38 & Timah (Persero) & TINS \\
\hline 17 & Berlina & BRNA & 39 & Trisula International & TRIS \\
\hline 18 & Budi Starch \& Sweetener & BUDI & 40 & $\begin{array}{l}\text { Ultra Jaya Milk Industry \& } \\
\text { Trading Company }\end{array}$ & ULTJ \\
\hline 19 & Bukit Uluwatu Villa & BUVA & 41 & United Tractors & UNTR \\
\hline 20 & Citra Marga Nusaphala Persada & CMNP & 42 & Wijaya Karya (Persero) & WIKA \\
\hline 21 & Intiland Development & DILD & 43 & Waskita Karya (Persero) & WSKT \\
\hline 22 & Elnusa & ELSA & & & \\
\hline
\end{tabular}

Source: $w w w . i d x . c o . i d$ 


\section{Data analysis}

Descriptive Statistics is applied to describe the main variable shown by the firm of graph in annual report for the period from 2012 to 2016. Descriptive statistics is also applied to describe the level of the firm effect to deliver information from 2012 to 2016. This analysis is applied to provide the illustration about the researched variable.

This research uses the model that will be applied to calculate panel data regression analysis and data processing uses Eview 9 program. This model is intended to prove the effect of firm size, profitability, leverage and firm growth on social responsibility disclosure by means of panel data regression analysis with the following equation :

$$
\mathrm{CSRDI}_{\mathrm{it}}=a+\beta 1 \text { Size }_{\mathrm{it}}+\beta 2 \text { Prof }_{\mathrm{it}}+\beta 3 \text { Lev }_{\mathrm{it}}+\beta 4 \text { Growth }_{\mathrm{it}}+\mathcal{E}
$$
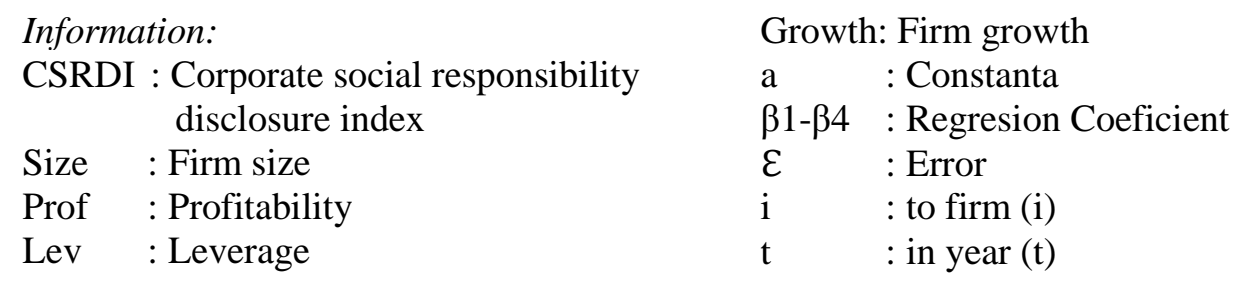

\section{RESULT AND DISCUSSION}

\section{Firm size}

It is measured by using the number of firm's assets, obtained from financial report at the end of period or in annual report. From the firm size variable measurement result it can be seen from the recapitulation table of firm size from the lowest to the highest for the period of 2012-2016, the date are as follows :

Table 2. Firm size variable recapitulation data

\begin{tabular}{llll}
\hline Year & Description & Code & Value \\
\hline \multirow{2}{*}{2012} & Maximum & INAF & 34.71 \\
& Minimum & ALKA & 25.72 \\
& Maximum & INAF & 34.80 \\
& Minimum & ALKA & 26.21 \\
& Maximum & INAF & 34.76 \\
& Minimum & ALKA & 26.22 \\
& Maximum & INAF & 34.97 \\
& Minimum & ALKA & 25.70 \\
& Maximum & INAF & 34.86 \\
& Minimum & ALKA & 25.64 \\
\hline
\end{tabular}

Source: Result of data processing

From the firm size recapitulation table it can be seen that in the period of 20122016 the highest value are obtained by PT. Indofarma (Persero), engaged in consumer goods industry where as the lowest in the period of 2012-2016 is PT. Alaka Industrindo, engaged in basic material and chemistry industry.

\section{Profitability}

The aim of profitability analysis is to measure the firm effect to gain profit, from either sales, assets or own capital. Profitability is measured by means of the ration of return in asset (ROA) in which the result is obtained from the division between net profit and total assets. 
From profitability variable measurement result it can be seen from the recapitulation table profitability from the lowest to the highest in the period of 2012-2016 it as follows :

Table 3. Recapitulation data of profitability variable

\begin{tabular}{llcr}
\hline Year & Description & Code & Value \\
\hline \multirow{2}{*}{2012} & Maximum & LPFF & 0.26 \\
& Minimum & BIPP & -0.08 \\
& Maximum & APLI & 6.20 \\
& Minimum & INAF & -0.04 \\
& Maximum & ISAT & 0.04 \\
\multirow{2}{*}{2015} & Minimum & ANTM & -0.04 \\
& Maximum & LPPF & 0.46 \\
& Minimum & ABBA & -0.11 \\
& Maximum & LPPF & 0.42 \\
& Minimum & INAF & -0.01 \\
& & SMCB & \\
\end{tabular}

Source: Result of data processing

From Table 3 it can be seen that the highest profitability value in 2012 was PT. Matahari Departement Store which is the firm engaged in trading, service and investment sectors with the profitability ratio value of 0.26 , where as the lowest firm was in property and real estate sectors, namely PT. Bhuwanatala Indah Permai with profitability ratio value of -0.08. in 2013 it was PT. Asiaplast Industries which got the highest value and is the firm engaged in manufacturing sector with the profitability ratio value 6.20 , where as the lowest one was PT. Indofarma (Persero) with the value of -0.04 .

In 2014 the highest value was reached by PT. Indosat which is the firm engaged in infrastructure, utility and transportation sectors with the profitability ratio value of 0.04 , where as the lowest was the mining firm, namely PT. Aneka Tambang (Persero) with the value of -0.04. In 2015 it was PT. Matahari Departement Store with the profitability ratio value of 0.46 , mean while the lowest was the firm engaged in trading, service and investment sectors namely PT. Mahaka Media with the value of -0.11. in 2016 the highest score was obtained by PT. Matahari Department Store with the profitability ratio value of 0.42 , on the contrary, the lowest one PT. Indofarma (Persero) and basic material and chemical industry firm, namely Holcim Indonesia with the value of -.0.01.

\section{Leverage}

Leverage shows the firm financial impact which describes the firm capital condition and understands the risk of being unable to collect debt. Then, it is measured by means of Debt to Equity Ratio (DER) which is obtained from the division result between the total liability and the total equity. From leverage variable measurement result, it can be seen from the recapitulation table, the leverage from the lowest to the highest in the period of 2012-2016.

From table 4 it can be seen that the highest leverage value in 2012 was PT. Waskita Karya (Persero) which is the firm engaged in property and real estate sectors with ratio value of 3.17. where as the lowest leverage value was PT. Matahari Department Store with ratio value of -2.52. in 2013 the highest leverage value was the basic material and chemical firm namely PT. Alakasa Industrindo with the value of 3.05, mean while the lowest was PT. Matahari Department Store with ratio value of -4.76 . 
Table 4. Recapitulation data of leverage variable

\begin{tabular}{llcr}
\hline Year & Description & Code & Value \\
\hline \multirow{2}{*}{2012} & Maximum & WSKT & 3.17 \\
& Minimum & LPPF & -2.52 \\
& Maximum & ALKA & 3.05 \\
& Minimum & LPPF & -4.76 \\
& Maximum & LPPF & 18.19 \\
\multirow{2}{*}{2015} & Minimum & BISI & 0.17 \\
& Maximum & EXCL & 3.18 \\
& Minimum & INAF & 0.16 \\
& Maximum & WSKT & 2.66 \\
& Minimum & BISI & 0.17 \\
\hline
\end{tabular}

Source: Result of data processing

In 2014, the highest leverage value was PT. Matahari Department Store with value of 18.19, where as the lowest was PT. BISI International which is the firm engagement in farming sector with the ratio value of 0.17 . In 2015 the highest leverage value was PT. XL Asiata, which is the firm engagement in infrastructure, utility and transportation with the value of 3.18, mean while the lowest was PT. Indofarma (Persero) with the ratio value of 0.16 .

In 2016 the highest leverage value was PT. Waskita Karya (Persero) with the value of 2.66, where as the lowest was PT. BISI International with the ratio value of 0.17 .

\section{Firm growth}

Firm Growth shows the firm's ability to complete with the other in the similar industry sector, and this ratio also measures firm growth from year to year in two indicators, namely : asset growth and sale growth. Firm growth is obtained with the formula where the sale is substracted and divided with the sale from the previous year.

From the firm growth variable measurement, it can be seen from the recapitulation table that firm growth from the lowest to the highest in the period of 2012-2016 is as follows :

Table 5. The recapitulation data of firm growth variable

\begin{tabular}{llcr}
\hline Year & Description & Code & Value \\
\hline \multirow{2}{*}{2012} & Maximum & ARTA & 1.56 \\
& Minimum & BISI & -0.13 \\
& Maximum & BIPP & 0.97 \\
& Minimum & WIKA & -0.81 \\
& Maximum & WIKA & 5.61 \\
\multirow{2}{*}{2014} & Minimum & AGII & 0.37 \\
& Maximum & AGII & 0.56 \\
& Minimum & INDF & -0.50 \\
& Maximum & BKSL & 1.16 \\
& Minimum & SDMU & -0.17 \\
\hline
\end{tabular}

\section{Source: Result of data processing}

Table 5 shows that the highest firm growth value in 2012 was PT. Artha Vest which is the firm engaged in financial sector with the ratio value of 1.56 , where as the lowest firm growth value was PT. BISI International with the ratio vaue of -0.13 . In 2013 the highest firm growth value was real estate firm, namely PT. Bhuwanatala Inda Permai 
eith the value of 0.97 . Where as the lowest was PT. Wijaya Karya (Persero) with ratio value of -0.81 .

In 2014 the highest firm growth value was PT. Wijaya Karya (Persero) with the value of 5.61 mean while the lowest was the mining firm, namely PT. Aneka Gas Industri with the ratio value of 0.37 . In 2015 the highest firm growth value was PT. Aneka Gas Industri with the of 0.56 , where as the lowest was the firm engaged in consumer's goods industry, namely PT. Indofood Sukses Makmur with the ratio value of -0.50. In 2016 the highest firm growth value was PT. Sentul City which is the firm engaged in property and real estate sectors with the value of 1.16, while the lowest was the firm engaged in infrastructure, utility and transportation sectors, namely: PT. Sindomulyo Selaras with the ratio value of 0.17 .

\section{Social responsibility disclosure}

All the firm activity which give direct effect to the environmental pollution will be the surrounding people's main concerns. This makes the firm require to apply CSR program to keep the environment Corporate Social Responsibility Disclosure Index (CSRDI) based on ISO 26000 Guidance Standard on Social Responsibility is the measuring tool used to measure the firm social responsibility disclosure. From Corporate Social Responsibility (CSR) variable measurement result, it can be seen from the recapitulation table that the corporate social responsibility variable from the lowest to the highest in the period of 2012-2016 are as follows :

Table 6. The recapitulation data of corporate social responsibility (CSR)

\begin{tabular}{llcc}
\hline Year & Description & Code & Value \\
\hline \multirow{2}{*}{2012} & Maximum & ASII & 0.94 \\
& Minimum & ABBA & 0.52 \\
& & APLI & 0.52 \\
& & ASRI & 0.52 \\
2013 & Maximum & ASII & 0.97 \\
& Minimum & ABBA & 0.52 \\
& Maximum & AISA & 0.97 \\
& & ASII & 0.97 \\
& Minimum & LPPF & 0.97 \\
& Maximum & ABBA & 0.52 \\
& & AISA & 0.97 \\
& & ASII & 0.97 \\
& Minimum & LPPF & 0.97 \\
& Maximum & ABBA & 0.52 \\
& & AISA & 0.97 \\
& & ASII & 0.97 \\
& Minimum & LPPF & 0.97 \\
& & ABBA & 0.52 \\
\hline
\end{tabular}

Source: Result of data processing

From Table 6 it can be seen that the highest CSR disclosure level in 2012 was PT. Astra International, which is the firm engaged in manufacturing sector with the value of 0.94, where as the lowest was the firm engaged in trading, service and investment, namely : PT. Mahaka Media, PT. Asia Plast Industries, and PT. Alam Sutera Realty are property and real estate with the value of 0.52. Then, in 2013 the highest CSR disclosure was reached again by PT. Astra International, with value of 0.97 , where as lowest was PT. Mahaka Media with the value 0.57. 
In 2014 the highest CSR disclosure levelwas PT. Tiga Pilar Sejahtera Food, which is the firm engaged in consumer's goods industry followed by PT. Astra International and PT. Matahari Department Store with the value of 0.97 and also in 2015 and 2016 where as the lowest CSR disclosure level was PT. Mahaka Media with the value of 0.52 till the years 2015 and 2016.

\section{Estimated result}

From the results that have been done by using the Chow Test and Hausman Test, obtained the effect method in this study, the method chosen is the Fixed Effect Method. The results of the Fixed Effect Method can be seen in the Table 7.

Table 7. Fixed effect method result

\begin{tabular}{|c|c|c|c|c|}
\hline Variable & Coefficient & Standard Error & t-Statistic & Prob. \\
\hline $\mathrm{C}$ & -2.108059 & 0.383090 & -5.502782 & 0.0000 \\
\hline UP? & 0.098083 & 0.013003 & 7.543292 & 0.0000 \\
\hline PROF? & 0.118528 & 0.017311 & 6.847065 & 0.0000 \\
\hline L? & 0.000165 & 0.000319 & 0.515066 & 0.6072 \\
\hline GRO? & -0.011956 & 0.008771 & -1.363069 & 0.1747 \\
\hline \multicolumn{5}{|c|}{ Fixed Effects (Cross) } \\
\hline AALI--C & -0.198155 & & & \\
\hline ABBA--C & -0.000391 & & & \\
\hline ACES--C & -0.141473 & & & \\
\hline AGII--C & 0.036557 & & & \\
\hline AISA--C & 0.058463 & & & \\
\hline ALKA--C & 0.234502 & & & \\
\hline ANTM--C & -0.105760 & & & \\
\hline APLI--C & -0.414292 & & & \\
\hline ARNA--C & 0.155412 & & & \\
\hline ARTA--C & 0.254941 & & & \\
\hline ASII--C & -0.180856 & & & \\
\hline ASRI--C & -0.313818 & & & \\
\hline BATA--C & 0.231453 & & & \\
\hline BIPP--C & 0.181710 & & & \\
\hline BISI--C & -0.078362 & & & \\
\hline BKSL--C & -0.161849 & & & \\
\hline BRNA--C & 0.150596 & & & \\
\hline BUDI--C & 0.023250 & & & \\
\hline BUVA--C & 0.031402 & & & \\
\hline CMNP--C & -0.081527 & & & \\
\hline DILD--C & -0.062759 & & & \\
\hline ELSA--C & 0.083886 & & & \\
\hline EXCL--C & -0.058815 & & & \\
\hline INAF--C & -0.486133 & & & \\
\hline INDF--C & -0.085478 & & & \\
\hline ISAT--C & -0.276354 & & & \\
\hline KAEF--C & 0.082650 & & & \\
\hline KBLM--C & 0.255313 & & & \\
\hline KLBF--C & -0.028402 & & & \\
\hline LPPF--C & 0.170399 & & & \\
\hline MYOR--C & -0.056981 & & & \\
\hline RALS--C & 0.013719 & & & \\
\hline ROTI--C & 0.132174 & & & \\
\hline SDMU--C & 0.337365 & & & \\
\hline SKBM--C & 0.149086 & & & \\
\hline SMCB--C & -0.034919 & & & \\
\hline SMGR--C & -0.057229 & & & \\
\hline TINS--C & 0.067239 & & & \\
\hline TRIS--C & 0.283019 & & & \\
\hline ULTJ--C & 0.074256 & & & \\
\hline UNTR--C & -0.187321 & & & \\
\hline WIKA--C & 0.014402 & & & \\
\hline WSKT--C & -0.010923 & & & \\
\hline \multicolumn{5}{|c|}{ Effects Specification } \\
\hline
\end{tabular}




\begin{tabular}{lllr}
\hline Cross-section fixed (dummy variables) & & & \\
\hline R-squared & 0.834114 & Mean dependent var & 0.781111 \\
Adjusted R-squared & 0.788693 & S.D. dependent var & 0.113661 \\
S.E. of regression & 0.052248 & Akaike info criterion & -2.875092 \\
Sum squared resid & 0.458617 & Schwarz criterion & -2.138254 \\
Log likelihood & 356.0723 & Hannan-Quinn criter. & -2.577375 \\
F-statistic & 18.36398 & Durbin-Watson stat & 1.421792 \\
Prob(F-statistic) & 0.000000 & & \\
\hline
\end{tabular}

Source: Eviews 9

This model has the assumption that individual difference can be accommodated in its intercept difference. In fixed effect model panel data estimation, dummy variable technique is used, so it can catch the intercept comparison from the firm from fixed effect result above, it can be seen that each firm has different intercept. The firm with the highest intercept value was PT. Sindomulyo Selaras with the value of -1.77069 , which is obtained from the firm's intercept result of 0.337365 added by regression equation constant of 2.10806 , on the contrary, the lowest was PT. Indofarma (Persero) with the value of 2.59419, which is obtained from the firm's intercept result of -0.486133 added by regression equation constant of -2.10806 . The intercept difference appears because of different managerial act, leadership and managerial culture, and incentive in each firm. However, the slop is the same among the firm's.

The descriptive statistic analysis equation test result shows the effect of the variable of firm size, profitability, leverage and firm growth individually. Firm size variable has the significance of 0.0000 , which is smaller than sig probability value or $0.000<0.05$ and the slop among firm is 0.098083 , which means that firm size has significant effect on CSR disclosure, hence $\mathrm{H} 1$ is accepted.

Profitability variable has the significance of 0.000 , which is smaller than sig probability value or $0.000<0.05$ and the slop among firms is 0.118528 , which means that profitability has significant effect on CSR disclosure, hence H2 is accepted.

Leverage variable has the significance of 0.6072 , which is bigger than sig profitability value or $0.6072>0.05$ and the slop among firms is 0.000165 , which means that leverage does not have significant effect on CSR disclosure, hence $\mathrm{H} 3$ is accepted.

Firm growth variable has the significance of 0.1747 , which is bigger than sig profitability value or $0.1747>0.05$ and the slop among firms is 0.011956 , which means that firm growth does not have significant effect on CSR disclosure and there fore, H4 is rejected.

\section{The effect of firm size on corporate social responsibility disclosure}

From the regression result it can be seen that firm size has significant effect corporate social responsibility disclosure with the probability amount of $0.0000<\alpha=005$ and the slop among the firms is 0.098083 , hence H1 in this research is accepted. From the result it can be illustrated that the more assets the firm has, the higher the social responsibility is to be disclosure it is relevant to the signaling theory, where the financial report was served by the firm management displays the information including the firm total assets. The displayed information can be used to take decision for the interest holders.

The evidence which emphasize that firm size has effect on social responsibility disclosure was discovered in the research done by Setiawan (2013) which stated that there is positive. Correlation between firm size whit significance value of 0.026 and coefficient of 0107. Big sale firm will not evade from the drive to give social responsibility. The source and financial from the firm has to provide its social responsibility information. 
Besides that, usually the firm has got public request about better in quality information than small scale firm (Setiawan et al, 2013).

\section{The effect of profitability on corporate social responsibility disclosure}

From the regression analysis result, it can be seen that profitability has significant effect on social responsibility disclosure with the amount of probability of $0.0000<$ $\alpha=005$ and the slop among the firm is about 0.118528 , hence $\mathrm{H} 2$ in the research is accepted. The result slows that the high level of profitability will make social responsibility disclosure getting more. This is the same with the signaling theory where the information in the firm of the reversion level towards the assets, namely the calculation from profitability or how much profit can be obtained from the expended assets : therefore, if the profitability is big, it will send good signal to the interest holders.

This result is relevant to the previous research performed by Widyawati (2012), which showed that there is significant effect between profitability and ISR or Islamic based Social Responsibility disclosure. The t-statistic amount shows the value of 3.819 with lower significance than the amount if significance $\alpha=5 \%$ is 0.000 . Therefore, profitability variable has positive and significant effect ISR disclosure level. The firm with high profit condition will give high quality information.

\section{The effect of leverage on corporate social responsibility disclosure}

From the regression analysis it can be seen that leverage does not have significant effect on social responsibility disclosure with the amount of probability of $0.6072>\alpha=$ 0.05 and the slop among the firms is 0.000165 : therefore, H3 in this research is accepted, the result shows how the level of relationship between the firm operational and debt is. Leverage shows the firm's financial risk because it can indicate the illustration of the early balance and know about the risk of the debt no to be collected. The high leverage in the firm will cause the big risk in financial, which then becomes the debt holders main attention. This thing is related to the signaling theory where it can be bad signal for the external parties from analysis the information about the high leverage in a firm.

This research in similar with the previous research performed by Putri (2014) who stated the t-statistic amount is -1.472 and the significance is smaller than the significance value of $0.150>\alpha=5 \%$ therefore, leverage does not have effect on CSR disclosure it is the case because many companies have admitted about how important social and the surrounding environment are, not only because it can gain profit, hence either high or low level of leverage does not have effect on CSR disclosure (Putri, 2014).

This result does not support the third hypothesis (H3) and the previous research which has the relationship with the effect of leverage on social responsibility disclosure has got the same amount as the research performed by Utami (2011), Sriayu (2013), Setiawan (2013), and Rindawati (2015). This research result shows that firm indeed has to reduce the financial risk by reducing the risk of the debts not to be collected because the high financial risk of the firm will be its own challenge in managing the firm and it will be difficult to disclose social responsibility.

\section{The effect of firm growth on social responsibility disclosure}

From the regression analysis calculation, it can be seen that firm growth does not have significant effect on social responsibility disclosure with the probability amount of $0.1747>\alpha=0.05$ and the slop between the firms is -0.0119 , therefore $\mathrm{H}_{4}$ in this research is rejected. This is relevant to the signaling theory where the rate of firm's sale is also reported in financial report, so it makes the external parties or the investors know the firm's sale development each year. However, in practice many firms endure instable sale 
from one year to the next one so that it causes the firm difficulty in disclosure social responsibility.

This research is relevant to the previous research performed by Sari (2012) who showed that firm growth variable which is measured with sale growth ratio based on $\mathrm{t}-$ test with t-count of -1.626 and significant of $0.111>\alpha=0.05$. it can be concluded that either high or low level of firm growth does not have effect social responsibility disclosure. This analysis does not support the fourth hypothesis $\left(\mathrm{H}_{4}\right)$ and the previous research dealing with the effect of firm growth on social responsibility disclosure (CSR) has got the same value as what Ani research (2015).

\section{CONCLUSION AND RECOMMENDATION}

\section{Conclusion}

Based on the research already performed, it can be conclude that Firm size partially has significant effect on corporate social responsibility disclosure. This result indicates that the bigger total assets the firm has, the more social responsibility disclosure the firm will have. Profitability partially has positive effect on corporate social responsibility. The highest level of profitability is the provides report of social responsibility disclosure the firm will have the provide. Leverage does not have effect on the corporate social responsibility disclosure. This research result describe that firm indeed has to reduce the financial risk by reducing the risk of the debt not to be collect. Firm growth does not have effect on corporate social responsibility disclosure. The conclusion of this research has revealed that many firms endure instable sales from one year to next year, so it makes firms difficult to disclose social responsibility.

\section{Recommendation}

The next research is expected to be able to add up the firm characteristic variable competent, so that there are more independent variables which have significant effect. The next research is expected to be able to select more specific object of research to be sample. The next research is expected to apply different effect model in selecting estimation model.

\section{REFERENCES}

Aini, Agustya Kurratul. (2015). Pengaruh Karakteristik Perusahaan Terhadap Pengungkapan Tanggung Jawab Sosial Perusahaan (CSR) Pada Perusahaan yang Terdaftar di Indeks LQ45 Bursa Efek Indonesia (BEI). Jurnal Kinerja. Vol. 12 No.1.

Andriyani, Rida dan Muhammad Khafid. (2014). Analisis Pengaruh Leverage, Ukuran Perusahaan dan Voluntary Disclosure Terhadap Manipulasi Aktifitas Rill. Accounting Analysis Journal Vol. 3 No. 3 pp. 273-281.

Anugrah, Rita., Roland, dan W. Faradilla. (2010). Pengaruh Ukuran Perusahaan, Leverage, dan Profitabilitas terhadap Pengungkapan Tanggung Jawab Sosial Perusahaan Pada Perusahaan Manufaktur yang Listing di BEI. Jurnal Ekonomi Vol. 18 No. 1

Arifianata, Ahmad Faris dan Agus Wahyudin. (2016). Karakteristik Perusahaan Terhadap Environmental Disclosure dengan Good Corporate Governanve Sebagai Pemoderasi. Acounting Analysis Journal Vol. 5 No. 2, pp: 47-56.

Arifin, Zaenal. (2005). Teori Keuangan dan Pasar Modal, Ekonosia, Yogyakarta, hal. 11. Brigham, Eungene F. dan Joel F. Houaton. (2001). Manajemen Keuangan, Erlangga, Jakarta, pp. 36. 
Chauhan, Swati and Amit. (2014). A relational study of firm's characteristics and CSR expenditure. Procedia Economics and Finance. Vol. 11 pp. 23-32.

Fauziah, Khusnul dan Prabowo Yudho Jayanto. (2013). Analisis Pengungkapan Tanggung Jawab Sosial Perbankan Syariah di Indonesia Berdasarkan Islamic Social Reporting Indeks. Jurnal Dinamika Akuntansi. Vol.5, No.1, Maret 2013, pp.12-20.

Feri, Mochamat. (2013). Pengaruh Rasio Profitabilitas Terhadap Perubahan Harga Saham Pada Perusahaan Sektor Properti Yang Listing di Bursa Efek Indonesia Periode 2008-2012. Jurnal Manajemen. Vol. 1 No. 6, Universitas Negeri Surabaya, Surabaya, pp. 1561.

Ghozali, Imam. (2009). "Aplikasi Analisis Multivariative dengan Program SPSS”. Badan Penerbit Unversitas Diponegoro: Semarang.

Ghozali, Imam dan Chariri. (2007). Teori Akuntansi International Financial Reporting. Semarang : Badan Penerbit Universitas Diponegoro.

Gray, R.H., Owen, D. and Adams, C. (1996), Accounting and Accountability, Prentice Hall, Hemel Hempstead.

Hastuti, Widya. (2014). Pengaruh Ukuran Perusahaan, Pertumbuhan Perusahaan, dan Tipe Industri Terhadap Pengungkapan Tanggung Jawab Sosial Perusahaan dalam Laporan Tahunan (Studi Empiris pada perusahaan Manufaktur yang listing di BEI).Jurnal Akuntansi. Vol 2 No. 2.Universitas Negeri Padang.

Imam, Wibowo dan Sekar. (2014). Dampak Pengungkapan Sustainability Report terhadap Kinerja Keuangan Perusahaan dan Pasar Perusahaan. Seminar Nasional Akuntansi 17

Iqbal, M. Dan T. Sudaryanto. (2008). Tanggung Jawab Sosial Perusahaan (Corporate Social Responsibility) dalam Prespektif Kebijakan Pembangunan Pertanian. Analisis Kebijakan Pertanian.Volume 6 No. 2, Juni 2008: 155- 173.

Jannah, Awalya Ma'rifatul dan Asrori. (2016). Pengaruh GCG, Size, Jenis Produk dan Kepemilikan Saham Publik terhadap Pengungkapan ISR. Accounting Analysis Journal. Vol. 5 No.1.Universitas Negeri Semarang.

Johansen, T.R.J. and Pettersson, K. (2013), "The impact of board interlocks on auditor choice and audit fees", Corporate Governance: An International Review, Vol. s21 No. 3, pp. 287-310.

Kamil dan Antonius. (2012). Pengaruh Karakteristik Perusahaan Terhadap Luas Pengungkapan Kegiatan Corporate Social Responsibility.Media Riset Akuntansi.Vol. 2 No. 1.

Khoirudin, Amirul. (2013). Corporate Governance dan Pengungkapan Islamic Social Reporting pada Perbankan Syariah di Indonesia. Accounting Analysis Journal.Vol. 2 No. 2. Universitas Negeri Semarang.

Kurnianingsih, Heni Triastusi. (2013). Pengaruh Profitabilitas dan Size Perusahaan Terhadap Corporate Social Responsibility.Jurnal Riset Akuntansi dan Bisnis. Vol. 13 No. 1.

Kretarto, Agus. (2001). Investor Relation: Pemasaran dan Komunikasi Keuangan Perusahaan Berbasis Kepatuhan, Grafiti Pers, pp. 53.

Marfuah dan Yuliawan Dwi Cahyono. (2011). Karakteristik Perusahaan dan Pengungkapan Tanggung Jawab Sosial. Jurnal Akuntansi Auditing Indonesia. Vol. 15 No. 1 pp. 103-115.

Marina, Yosy. (2013). Pengaruh Karakteristik Perusahaan Terhadap Pengungkapan Tanggung Jawab Sosial : Study Empiris pada Perusahaan Pertambangan. Jurnal Mahasiswa. Vol 1.No. 1. Universitas Andalas. 
Maulida, Aldehita Purnasanti, Agung dan Asrori. (2014). Analisis Faktor-faktor yang Mempengaruhi Pengungkapan Islamic Social Reproting (ISR).SNA 17 Mataram, Lombok. 24-27 September 2014.

Munsaidah, Siti., Rita dan Agus Supriyanto. (2016). Analisis Pengaruh Firm Size, Age, Profitabilitas, Leverage, dan Growth Perusahaan Terhadap Corporate Social Responsibility (CSR) Pada Perusahaan Property dan Real Estate yang Terdaftar di Bursa Efek Indonesia pada Tahun 2010-2014. Journal Of Accounting. Vol. 2 No.2.

Ningrum, Ratna Aditya, Fachrurrozie dan Prabowo Y.J. (2013). Pengaruh Kinerja Keuangan, Kepemilikan Institusional dan Ukuran Dewan Pengawas Syariah Terhadap Pengungkapan ISR. Accounting Analysis Journal.Vol. 2 No. 4.Universitas Negeri Semarang.

Novita Indrawati. (2009). Pengungkapan Corporate Social Responsibility (CSR) dalam Annual Report serta Pengaruh Political Visibility dan Economic Performance.Pekbis Jurnal. Vol.1, No.1, Maret 2009: 1-11. Universitas Riau

Nugroho, Mirza Nurdin dan Agung Yulianto. (2015). Pengaruh Profitabilitas dan Mekanisme Corporate Governance Terhadap Pengungkapan CSR Perusagaan Terdaftar JII 2011-2013. Accounting Analysis Journal Vol. 4 No. 1 pp. 1-12.

Nurnaeni dan Antin Rakhmawati. (2016). Pengaruh Karakteristik Perusahaan Terhadap Pengungkapan Corporate Social Responsibility Pada Perusahaan Food \& Beverage yang Listing di Bursa Efek Indonesia (BEI) Periode 2009-2013. Jurnal Yudharta. Vol. 1 No. 1.

Oktania, Anne Erika. (2013). Analisis Profitabilitas dan Likuiditas dalam Menilai Kinerja Keuangan Pada PT. Telekomunikasi Indonesia, Tbk. Jurnal Ilmu \& Riset Manajemen Vol. 2 No. 3.

Pratiwi, Dyah Putri. (2017). Pengaruh Growth Opportunity, Profitabilitas dan Ukuran Perusahaan Terhadap Nilai Perusahaan. Jurnal Ilmu dan Riset Akuntansi Vol. 6, No. 2.

Putri, Rafika Anggraini dan Yulius Jogi Christiawan. (2014). Pengaruh Profitabilitas, Likuiditas dan Leverage terhadap Pengungkapan Corporate Social Responsibility (Studi Pada Perusahaan-perusahaan yang mendapat penghargaan ISRA dan Listed (Go-Public) di Bursa Efek Indonesia (BEI) 2010-2012). Business Accounting Review. Vol 2.No.1.

Purba, Ide Bagus Gde Indra Wedhana dan Putu Yadnya. (2015). Pengaruh Ukuran Perusahaan dan Leverage Terhadap Profitabilitas dan Pengungkapan Corporate Social Responsibility.E-Jurnal Manajemen Unud.Vol. 4 No. 8.

Purwanto, Agus. (2011). Pengaruh Tipe Industri, Ukuran Perusahaan, Profitabilitas terhadap Corporate Social Responsibility. Jurnal Akuntansi \& Auditing Vol 8 No. 1 .

Rawi dan M. Muchlish. (2010). "Kepemilikan Manajemen, Kepemilikan Institusi, Leverage dan Corporate Social Responsibility”. Simposium Nasional Akuntansi XIII.Purwokerto.

Rindawati, Meita Wahyu dan Nur Fadjri Asyik. (2015). Pengaruh Profitabilitas, Ukuran Perusahaan, Leverage, dan Kepemilikan Publik Terhadap Pengungkapan Corporate Social Responsibility (CSR). Jurnal Ilmu \& Riset Akuntansi.Vol. 4 No. 6.

Rosiana, E. G., Juliarsa, G., dan Sari M. (2013). Pengaruh Pengungkapan CSR tehadap Nilai Perusahaan dengan Profitabilitas sebagai variabel Pemoderasi. E-Jurnal Akuntansi Universitas Udayana, 5(3),723-738 
Sari, Rizkia Anggita. (2012). Pengaruh Karakteristik Perusahaan Terhadap Corporate Social Responsibility Disclosure Pada Perusahaan Manufaktur yang Terdaftar di Bursa Efek Indonesia.Jurnal Nominal. Volume 1 Nomor 1.Universitas Negeri Yogyakarta.

Sembiring, Eddy Rismanda. (2006). "Karakteristik Perusahaan dan Pengungkapan Tanggung Jawab Sosial: Study Empiris pada Perusahaan yang Tercatat di Bursa Efek Jakarta".Jurnal Maksi Universitas Diponegoro Semarang.Vol. 6, No. 1, Januari, pp.69-85.

Setiawati, Erma., Zulfikar, dan Riza Artha. (2013). Pengaruh Karakteristik Perusahaan Terhadap CSR (Survey pada Industri Perbankan di Indonesia). Proceeding Seminar Nasional dan Call For Papers Sancall 2013. Surakarta.

Setyo, Arum Mestuti. (2012). Analisis Pengaruh Manajemen Laba terhadapTanggung Jawab Sosial dan Lingkungan dengan Corporate Governance sebagai Variabel Moderating: Studi Kasus pada Perusahaan Manufaktur yang Terdaftar di BEI tahun 2009-201. Fakultas Ekonomika dan Bisnis, Universitas Diponegoro

Sriayu, Gusti Ayu Putu Wiwik dan Ni Putu Sri Harta Mimba (2013).Pengaruh Karakteristik Perusahaan Terhadap CSR Disclosure.E-Jurnal Akuntansi Universitas UdayanaVol. 5. No. 2 pp. 326-344.

Sudarmadji, Ardi dan Lana Sularto. (2007). "Pengaruh Ukuran Perusahaan, Profitabilitas, leverage, dan Tipe Kepemilikan Perusahaan Terhadap Luas Voluntary Disclosure Laporan Keuangan Tahunan", Proceeding PESAT, Volume 2.

Tunggal, Amin Widjaja. (2008). Dasar - Dasar Customer Relationship Management (CRM). Jakarta : Harvindo.

Utami, Sri dan Sawitri Dwi Prastiti. (2011). Pengaruh Karakteristik Perusahaan terhadap Social Disclosure.Jurnal Ekonomi Bisnis. Vol. 16.No. 1. pp. 63-69.

Veronica, Theodora Martina. (2015). "Pengaruh Karakteristik Perusahaan Terhadap Pengungkapan Tanggung Jawab Sosial Pada Perusahaan Sektor Pertambangan yang Terdaftar di Bursa Efek Indonesia”. Jurnal Ilmiah Ekonomi Bisnis. Vol. 20 No.2. pp. 1-11.

Wakid, Nadia Lutfi., Iwan, dan Prihat. (2013). Pengaruh Karakteristik Perusahaan Terhadap Pengungkapan Corporate Social Responsibilty Pada Perusahaan Manufaktur yang Terdaftar di Bursa Efek Indonesia. Journal El-Muhasaba.Vol. 4 No.1. pp. 1-27.

Wibisono, Yusuf. (2007). Membedah Konsep \& Aplikasi CSR (Corporate Social Responsibility), Gresik: Fasch Publising.

Widiawati, Septi dan Surya Raharja. (2012). Analisis Faktor-Faktor yang Mempengaruhi Islamic Social Reporting Perusahaan-Perusahaan yang Terdapat pada Daftar Efek Syariah Tahun 2009-2011.Diponegoro Journal of Accounting. Volume 1 Nomor 2. pp. $1-15$

Zuhroh, Diana dan I Putu Pande Heri Sukmawati. (2003). "Analisis Pengaruh Luas Pengungkapan Sosial dalam Laporan Tahunan Perusahaan terhadap Reaksi Investor". Simposium Nasional Akuntansi VI. Surabaya. 